Atmos. Chem. Phys., 19, 11089-11103, 2019

https://doi.org/10.5194/acp-19-11089-2019

(C) Author(s) 2019. This work is distributed under

the Creative Commons Attribution 4.0 License.

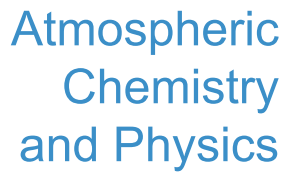

(c) (i)

\title{
How marine emissions of bromoform impact the remote atmosphere
}

\author{
Yue Jia ${ }^{1}$, Susann Tegtmeier ${ }^{1}$, Elliot Atlas ${ }^{2}$, and Birgit Quack ${ }^{1}$ \\ ${ }^{1}$ GEOMAR Helmholtz Centre for Ocean Research Kiel, Kiel, Germany \\ ${ }^{2}$ University of Miami, 4600 Rickenbacker Causeway, Miami, USA \\ Correspondence: Yue Jia (yjia@geomar.de)
}

Received: 13 November 2018 - Discussion started: 14 December 2018

Revised: 29 May 2019 - Accepted: 23 July 2019 - Published: 3 September 2019

\begin{abstract}
It is an open question how localized elevated emissions of bromoform $\left(\mathrm{CHBr}_{3}\right)$ and other very short-lived halocarbons (VSLHs), found in coastal and upwelling regions, and low background emissions, typically found over the open ocean, impact the atmospheric VSLH distribution. In this study, we use the Lagrangian dispersion model FLEXPART to simulate atmospheric $\mathrm{CHBr}_{3}$ resulting from assumed uniform background emissions, and from elevated emissions consistent with those derived during three tropical cruise campaigns.

The simulations demonstrate that the atmospheric $\mathrm{CHBr}_{3}$ distributions in the uniform background emissions scenario are highly variable with high mixing ratios appearing in regions of convergence or low wind speed. This relation holds on regional and global scales.

The impact of localized elevated emissions on the atmospheric $\mathrm{CHBr}_{3}$ distribution varies significantly from campaign to campaign. The estimated impact depends on the strength of the emissions and the meteorological conditions. In the open waters of the western Pacific and Indian oceans, localized elevated emissions only slightly increase the background concentrations of atmospheric $\mathrm{CHBr}_{3}$, even when $1^{\circ}$ wide source regions along the cruise tracks are assumed. Near the coast, elevated emissions, including hot spots up to 100 times larger than the uniform background emissions, can be strong enough to be distinguished from the atmospheric background. However, it is not necessarily the highest hot spot emission that produces the largest enhancement, since the tug-of-war between fast advective transport and local accumulation at the time of emission is also important.
\end{abstract}

Our results demonstrate that transport variations in the atmosphere itself are sufficient to produce highly variable
VSLH distributions, and elevated VSLHs in the atmosphere do not always reflect a strong localized source. Localized elevated emissions can be obliterated by the highly variable atmospheric background, even if they are orders of magnitude larger than the average open ocean emissions.

\section{Introduction}

Very short-lived halocarbons (VSLHs) with atmospheric lifetimes shorter than 6 months from natural oceanic sources are dominated by brominated and iodinated compounds (Carpenter and Liss, 2000; Quack et al., 2004; Law et al., 2006). VSLHs have drawn considerable interest due to their contribution to stratospheric ozone depletion and tropospheric chemistry (Solomon et al., 1994; Dvortsov et al., 1999; Salawitch et al., 2005; Feng et al., 2007; Tegtmeier et al., 2015; Hossaini et al., 2015). In this work, we focus on the VSLH bromoform $\left(\mathrm{CHBr}_{3}\right)$ since most organic oceanic bromine is released into the atmosphere in this form.

$\mathrm{CHBr}_{3}$ concentrations measured in ocean waters are characterized by large spatial variability with elevated abundances in phytoplankton blooms (Baker et al., 2000; Liu et al., 2013) and equatorial and upwelling regions due to biological sources (Carpenter et al., 2009; Quack and Wallace, 2003; Quack et al., 2007; Fuhlbrügge et al., 2016). The open ocean generally shows homogeneous, low $\mathrm{CHBr}_{3}$ concentrations, compared to higher concentrations and strong gradients found in coastal and shelf areas (Quack and Wallace, 2003). At the coast, high oceanic concentrations are related to macro-algae (Klick and Abrahamsson, 1992) and anthropogenic sources (Boudjellaba et al., 2016) such as 
power plants (Yang, 2001) and desalination facilities (Agus et al., 2009).

Due to sparse measurements and limited process understanding, existing estimates of global air-sea flux distributions of $\mathrm{CHBr}_{3}$ and other VSLHs are subject to large uncertainties (e.g., Warwick et al., 2006; Palmer and Reason, 2009; Liang et al., 2010; Ordóñez et al., 2012; Stemmler et al., 2013; Ziska et al., 2013; Carpenter et al., 2014). The spatial and temporal distribution of elevated emissions in coastal and upwelling regions is currently based on limited observations. Campaigns in these regions suggest that emissions generally increase near coastlines, and that sporadic peak emissions with extremely high values can be found (e.g., Butler et al., 2007; Liu et al., 2013; Fuhlbrügge et al., 2016; Fiehn et al., 2017). Analysis of the measurements suggests that such peak emissions are often of limited spatial extent and cover not more than a distance of $50-100 \mathrm{~km}$ along the cruise track.

There are two main approaches to derive the magnitude of VSLH emissions, i.e., the "bottom-up" approach (e.g., Quack and Wallace, 2003; Carpenter and Liss, 2000; Butler et al., 2007; Ziska et al., 2013) and the "top-down" approach (e.g., Warwick et al., 2006; Liang et al., 2010; Ordóñez et al., 2012). For the bottom-up method, measured surface seawater concentrations of VSLHs at the "bottom" (surface) are extrapolated to estimate global emissions. For the top-down method, the emissions of VSLHs are constrained by the measured abundances at the "top" (atmosphere) so that model simulations based on the constrained global emission estimates reproduce the observed atmospheric concentrations. These two approaches yield different estimates of the global VSLHs emissions, with the recent top-down approaches resulting in generally higher emissions than the recent bottomup approaches.

In the tropical ocean waters of the Atlantic and the western Pacific and Indian oceans, the existence of localized elevated $\mathrm{CHBr}_{3}$ emissions and hot spots has been confirmed (Butler et al., 2007; Liu et al., 2013; Krüger and Quack, 2013; Fiehn et al., 2017). At the same time, these convectively active regions offer an efficient pathway for the vertical transport of short-lived oceanic compounds from the boundary layer to the stratosphere (e.g., Aschmann et al., 2009; Hossaini et al., 2012; Tegtmeier et al., 2012, 2013; Marandino et al., 2013; Liang et al., 2014). Moreover, the Asian monsoon has been recognized as an efficient transport pathway for short-lived pollutants and VSLHs (Randel et al., 2010; Hossaini et al., 2016; Fiehn et al., 2017). Given that elevated oceanic $\mathrm{CHBr}_{3}$ emissions are expected to occur in the same regions as strong convection, it is of interest to analyze how these elevated emissions impact $\mathrm{CHBr}_{3}$ in the atmospheric boundary layer, which feeds into the upward transport.

Measurements of $\mathrm{CHBr}_{3}$ abundance in the atmospheric boundary layer show large spatial variability (e.g., Quack and Wallace, 2003; Montzka and Reimann, 2011; Lennartz et al., 2017). A compilation of available measurements by Ziska et al. (2013) suggests similar $\mathrm{CHBr}_{3}$ distribution patterns in the atmospheric boundary layer as in the surface ocean, with higher mixing ratios in the equatorial, coastal, and upwelling regions. However, given the sparse base of data and the uncertainties in the spatial and temporal extent of oceanic emissions, the detailed distribution of boundary layer $\mathrm{CHBr}_{3}$ cannot be well constrained (e.g., Hepach et al., 2014; Fuhlbrügge et al., 2013). On the one hand, the spatial and temporal extent of elevated localized emissions is usually unknown, leading to large uncertainties when estimating their overall magnitudes. On the other hand, the influence of meteorological conditions, distinctive transport patterns, and variations in atmospheric sinks, such as the background $\mathrm{OH}$ field (e.g., Rex et al., 2014), can be expected to modulate the effect of elevated oceanic sources. Knowledge about the interplay between sources, transport, and loss processes is relevant to understand the importance of localized elevated emissions for atmospheric abundances and to interpret existing atmospheric measurements with respect to potential sources and driving factors.

In this study, we use observational data from three tropical research cruises, one in the Indian Ocean (OASIS) and two in the western Pacific (TransBrom and SHIVA). We use the Lagrangian particle dispersion model FLEXPART to investigate the transport and atmospheric distribution of VSLHs. Taking bromoform as an example, we compare the atmospheric signals estimated from the elevated and hot spot emissions measured during the ship campaigns to the distribution derived from only uniform background emissions. We use the term "elevated emissions" when describing emissions that are on average up to a factor of 10 larger than the background and "hot spot emissions" for sporadic emissions up to a factor of 100 larger than the background. The campaigns and the FLEXPART model are introduced in Sect. 2. In Sect. 3, we discuss the distributions and variability of atmospheric $\mathrm{CHBr}_{3}$ based on uniform background emissions. We present the observed hot spots of $\mathrm{CHBr}_{3}$ emissions in Sect. 4.1, and compare the simulated atmospheric mixing ratios resulting from elevated emissions during three campaigns with the background values in Sect. 4.2. Conclusions are given in Sect. 5.

\section{Data and methods}

\subsection{Background and in situ $\mathrm{CHBr}_{3}$ emissions}

In this study, we distinguish between open ocean background and in situ $\mathrm{CHBr}_{3}$ emissions. Open ocean emissions are inferred to be around $100 \mathrm{pmol} \mathrm{h}^{-1} \mathrm{~m}^{-2}$ based on global bottom-up scenarios (Quack and Wallace, 2003; Butler et al., 2007; Liu et al., 2013; Fiehn et al., 2017; Ziska et al., 2013). While emissions for individual regions and seasons can be higher or lower than this, including negative fluxes going from the atmosphere into the ocean, 


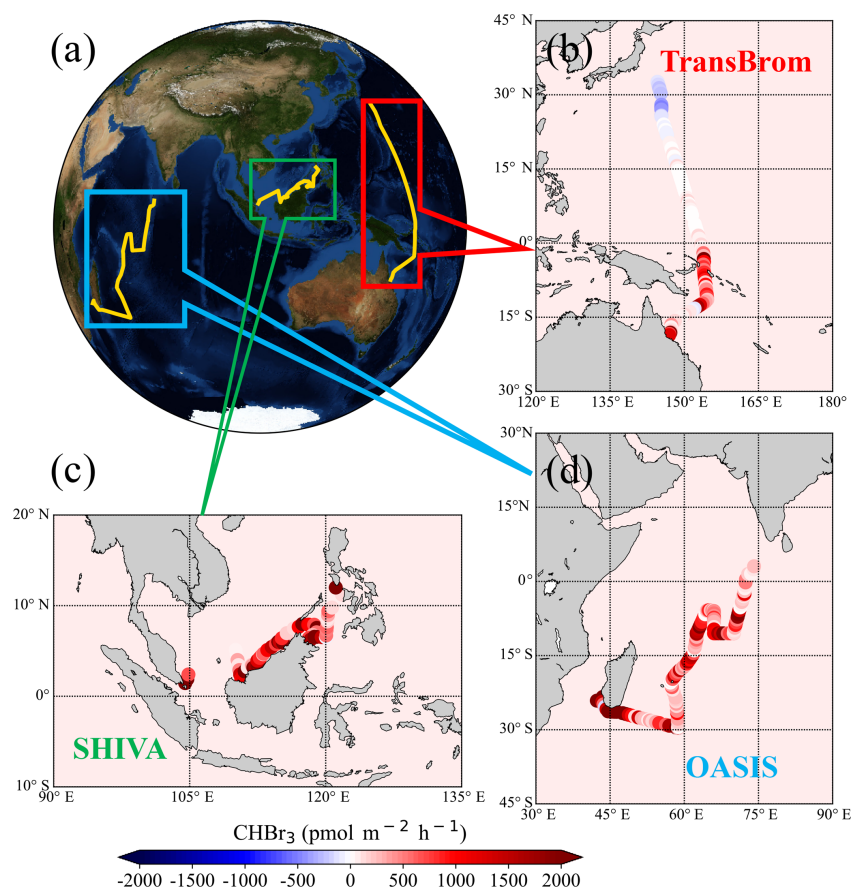

Figure 1. Cruise tracks of the three campaigns in the Indian Ocean and western Pacific (a) and $\mathrm{CHBr}_{3}$ emissions (b, c, d) used in the model simulation. Global background emissions $\left(100 \mathrm{pmol} \mathrm{m}^{-2} \mathrm{~h}^{-1}\right)$ and observed emissions along the tracks of the three research cruises TransBrom (b), SHIVA (c), and OASIS (d).

$100 \mathrm{pmol} \mathrm{h}^{-1} \mathrm{~m}^{-2}$ represents a typical mean value averaged over all oceanic basins between $60^{\circ} \mathrm{S}$ and $60^{\circ} \mathrm{N}$. The background open ocean emissions exclude by design emissions from coastal, shelf, and upwelling regions.

In situ oceanic emissions of $\mathrm{CHBr}_{3}$ have been calculated from the observational data collected during three tropical ship campaigns. During each campaign, surface air and water samples were collected simultaneously at regular intervals (every 3 to $6 \mathrm{~h}$ ). The emissions were calculated from these co-located data and the instantaneous wind speed (Ziska et al., 2013; Fuhlbrügge et al., 2016; Fiehn et al., 2017). The air-sea flux was obtained from the transfer coefficient $\left(k_{\mathrm{w}}\right)$ and the concentration gradient $(\Delta c)$ between water concentration and the theoretical equilibrium water concentration (see details in Fiehn et al., 2017, and references therein):

$F=k_{\mathrm{W}} \cdot \Delta c$.

The two campaigns TransBrom (11-23 October 2009) and SHIVA (15-28 November 2011) took place in the western Pacific, while the OASIS campaign (11 July-6 August 2014) was conducted in the western Indian Ocean. The detailed cruise track and the magnitude of the oceanic $\mathrm{CHBr}_{3}$ emissions of each campaign are given in Fig. 1. The in situ emissions include both open-ocean emissions and elevated emissions from coastal, shelf, and upwelling regions.

\subsection{Modeling}

For the simulations of the atmospheric distribution and transport of $\mathrm{CHBr}_{3}$, we used the Lagrangian particle dispersion model, FLEXPART (Stohl et al., 2005), which has been validated by previous comparisons with measurements (Stohl et al., 1998; Stohl and Trickl, 1999). Lagrangian particle models such as FLEXPART compute trajectories of a large number of so-called particles, presenting infinitesimally small air parcels, to describe the transport, diffusion, and chemical decay of tracers in the atmosphere. The model includes turbulence in the boundary layer and free troposphere (Stohl and Thomson, 1999) and a moist convection scheme (Forster et al., 2007) following the parameterization by Emanuel and Živković-Rothman (1999). The representation of convection in FLEXPART simulations has been validated with tracer experiments and ${ }^{222} \mathrm{Rn}$ measurements (Forster et al., 2007). Chemical or radioactive decay of the transported tracer is accounted for by reducing the tracer mass in the air parcels according to a prescribed lifetime of the tracer. Alternatively, the loss processes can be prescribed via $\mathrm{OH}$ reaction based on a monthly averaged three-dimensional $\mathrm{OH}$ field. In this study, we employ FLEXPART version 10.0, which is driven by 3-hourly meteorological fields from ECMWF (European Centre for Medium-Range Weather Forecasts) reanalysis product ERA-Interim (Dee et al., 2011) with a horizontal resolution of $1^{\circ} \times 1^{\circ}$ and 61 vertical model levels.

We performed two kinds of simulations based on the different emissions scenarios. The first one used the uniform global background emissions, and the second one used in situ emissions observed during individual ship campaigns. Trajectories released from the global ocean surface or along the cruise track carry the amount of $\mathrm{CHBr}_{3}$ prescribed by the respective emissions scenario. Chemical decay of $\mathrm{CHBr}_{3}$ was accounted for by

$m(t+\Delta t)=m(t) \exp (-\Delta t / \beta)$,

where $m$ is the mass of $\mathrm{CHBr}_{3}$ in the air parcel, $\beta=$ $T_{1 / 2} / \ln (2)$ is the $e$-folding lifetime of $\mathrm{CHBr}_{3}$, and $T_{1 / 2}$ is the half-life of $\mathrm{CHBr}_{3}$ (Stohl et al., 2005). In our study, a half-life of $17 \mathrm{~d}$ ( $e$-folding lifetime of $24 \mathrm{~d}$ ) is prescribed for $\mathrm{CHBr}_{3}$ during all runs (Montzka and Reimann, 2011). For the background runs, a uniform air-sea flux of $100 \mathrm{pmol} \mathrm{h}^{-1} \mathrm{~m}^{-2}$ was prescribed over all ocean surface area between $60^{\circ} \mathrm{S}$ and $60^{\circ} \mathrm{N}$. Three runs were conducted covering the time period of the campaigns with a 1-month spin-up period in each case to reach a stable background concentration in the atmosphere.

For the in situ emissions of each campaign, simulations were based on the calculated $\mathrm{CHBr}_{3}$ air-sea flux (see Fig. 8), which was released along the cruise track. The periods of the corresponding background simulations with emissions over the whole time period were the same as the campaign simulations. For each observational data point, an emission grid cell centered on the measurement location was cre- 
ated. These grid cells were designed to be adjacent along the cruise track and, based on the density of the measurements, were about $0.1-2.0^{\circ}$ wide in the cruise track direction. The grid cells were chosen to be of a fixed width $(0.5$ or $\left.1^{\circ}\right)$ in the other direction and thus add up to the narrow band of 0.5 or $1^{\circ}$ width centered along the cruise track (Fig. 1). Our design of the emission grid cells assumes that the elevated emissions can extend over a distance of $0.5-1^{\circ}$. This choice has been motivated by the spatial variability of the measurements along the cruise track (see also Sect. 4.1 and Fig. 7). Elevated emissions larger than $1000 \mathrm{pmol} \mathrm{h}^{-1} \mathrm{~m}^{-2}$ were found at 77 different locations along the three cruise tracks examined in this paper. Out of the 77 measurements, only 11 corresponded to singular locations with no adjacent high emissions at the neighboring points. The other 66 measurements are clustered together at 18 different locations with at least two adjacent observational points showing emissions larger than $1000 \mathrm{pmol} \mathrm{h}^{-1} \mathrm{~m}^{-2}$. We defined the length of such a location of elevated emissions as the distance between the first and last data point with an air-sea flux exceeding $1000 \mathrm{pmol} \mathrm{h}^{-1} \mathrm{~m}^{-2}$. Most of the 18 locations extended over a distance larger than $0.5^{\circ}$ (13 out of 18) and nearly half were larger than $1^{\circ}$ (8 out of 18), supporting our choice of the width of the emissions grid cells. Note that the spatial extent of the hot spots was comparable to the wind field resolution that drove our trajectory simulations. The amount of $\mathrm{CHBr}_{3}$ released from each grid cell was determined by the observational air-sea flux of the corresponding data point and scaled with the width of the narrow emission band described above. The specified $\mathrm{CHBr}_{3}$ emission from each cell was kept constant for the duration of the model run and distributed over a fixed number of trajectories. In order to capture the small-scale processes (e.g., convection), the 2000 trajectories were released from each $1^{\circ} \times 1^{\circ}$ area of background runs and 20000 from each emission grid of regional in situ runs.

Output data in the form of $\mathrm{CHBr}_{3}$ volume mixing ratios (VMRs) available on a user-defined grid were calculated by

$\mathrm{VMR}=\left(\frac{C_{\mathrm{T}}}{\rho_{\mathrm{a}}}\right) \cdot\left(\frac{m_{\mathrm{a}}}{m_{\mathrm{T}}}\right)$,

where $C_{\mathrm{T}}$ is the $\mathrm{CHBr}_{3}$ mass concentration, $\rho_{\mathrm{a}}$ is the density of the air, and $m_{\mathrm{a}}$ and $m_{\mathrm{T}}$ are the molecular weight of air and $\mathrm{CHBr}_{3}$, respectively.

For each grid cell, the $\mathrm{CHBr}_{3}$ mass concentration is given by

$C_{\mathrm{T}}=\frac{1}{V} \sum_{i=1}^{N} m_{i} f_{i}$,

with $m_{i}$ being the mass of $\mathrm{CHBr}_{3}$ for air parcel $i, f_{i}$ the mass fraction of $\mathrm{CHBr}_{3}$ of parcel $i$ attributed to the respective grid cell, $N$ the total number of the air parcels, and $V$ the volume of the grid cell (Stohl et al., 2005). We run FLEXPART in the non-domain-filling mode; therefore the parcel distribution is not correlated with air density. Air parcels, and thus bromoform, can accumulate in regions of low wind speeds where the relatively long residence time allows oceanic emissions to constantly add new parcels. Similarly, parcels can accumulate in regions of convergence where horizontal inflow pools marine boundary layer air from different regions. The output files are recorded at a horizontal resolution of $1^{\circ} \times 1^{\circ}$ and $0.5^{\circ} \times 0.5^{\circ}$ for background runs and in situ runs, respectively, at every $100 \mathrm{~m}$ from $100 \mathrm{~m}$ to $1 \mathrm{~km}$ altitude, and every $1 \mathrm{~km}$ from 1 to $20 \mathrm{~km}$ altitude every $3 \mathrm{~h}$.

\section{Atmospheric $\mathrm{CHBr}_{3}$ based on open ocean background emissions}

In this section, we show the impact of atmospheric transport patterns on the atmospheric $\mathrm{CHBr}_{3}$ distribution, with the uniform background $\mathrm{CHBr}_{3}$ emission simulations. The $\mathrm{CHBr}_{3}$ mixing ratios in the lower atmosphere diagnosed from the uniform background emissions (referred to as $\mathrm{CHBr}_{3}$ background mixing ratios hereinafter) vary significantly from campaign to campaign and also within each campaign region. Figures 2 to 4 present snapshots of the $\mathrm{CHBr}_{3}$ background mixing ratios and the simultaneous wind fields from ERA-Interim for the three campaigns. For TransBrom (Fig. 2), high $\mathrm{CHBr}_{3}$ mixing ratios appear south of $15^{\circ} \mathrm{N}$ with a maximum near the Equator, where the wind is weak. In the northern Pacific, which is dominated by an anticyclone centered around $165^{\circ} \mathrm{E}, 30^{\circ} \mathrm{N}$, the background values are much lower. On 10 October 2009, two bands of extremely low wind fields exist, one directly south of the Equator and one tilting from 15 to $5^{\circ} \mathrm{N}$, which both coincide with the highest $\mathrm{CHBr}_{3}$ abundances. On 20 October, these two bands collided into one with the lowest winds centered around $165^{\circ} \mathrm{E}$, where we again find very high values of $\mathrm{CHBr}_{3}$ of up to $0.8 \mathrm{ppt}$. For both case studies, the highest values are found in the region of the lowest wind speeds or slightly shifted towards the region of strongest wind shear. Regions of high wind speeds, such as the northern Pacific anticyclone, are characterized by very low $\mathrm{CHBr}_{3}$.

For the SHIVA case (Fig. 3), the background $\mathrm{CHBr}_{3}$ accumulates in a narrow region near Indonesia, with corresponding wind fields smaller than $3 \mathrm{~m} \mathrm{~s}^{-1}$. North of Indonesia, the strong easterly trade winds generally above $10 \mathrm{~m} \mathrm{~s}^{-1}$ prevent the accumulation of higher background values within the region. Again, the two case studies illustrate how changes of the wind patterns within a few days drive changes of the background $\mathrm{CHBr}_{3}$ distribution. Another particular example is the northward extension of the low equatorial winds around $90^{\circ} \mathrm{E}$ on 16 November 2011, which leads to higher $\mathrm{CHBr}_{3}$ north of the Equator up to $15^{\circ} \mathrm{N}$.

For OASIS (Fig. 4), the wind speed is higher than for the other two campaigns and these strong southeast/southwest trade winds associated with the Asian monsoon extend over most of the Indian Ocean. Consistent with the stronger 


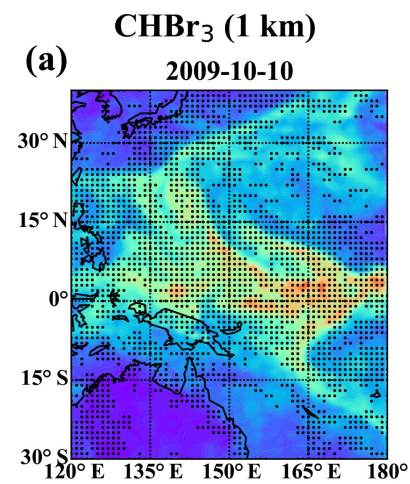

(c)

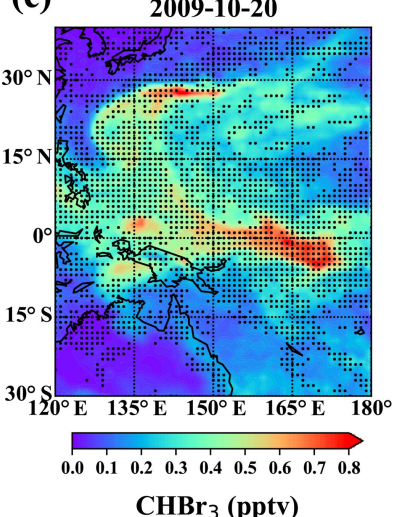

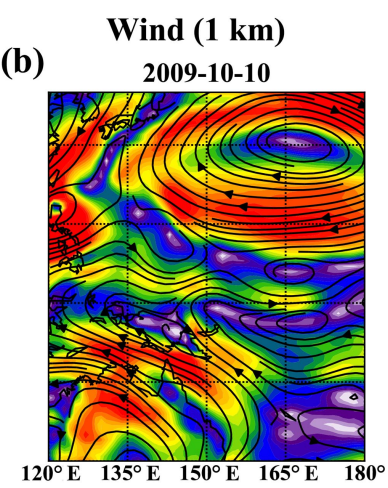

(d)

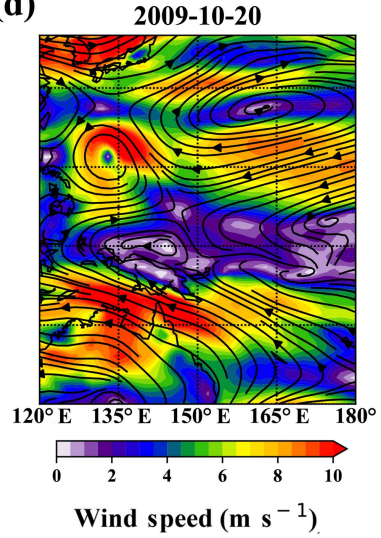

Figure 2. Two snapshots of spatial distributions of atmospheric $\mathrm{CHBr}_{3}$, derived from uniform oceanic background emissions of $100 \mathrm{pmol} \mathrm{m}^{-2} \mathrm{~h}^{-1}(\mathbf{a}, \mathbf{c})$ and ERA-Interim reanalysis wind fields $(\mathbf{b}, \mathbf{d})$ at $1 \mathrm{~km}$ altitude during TransBrom. The wind speed is denoted by color shades and the directions are denoted by the stream lines. The regions of convergence are shaded in $(\mathbf{a}, \mathbf{c})$.
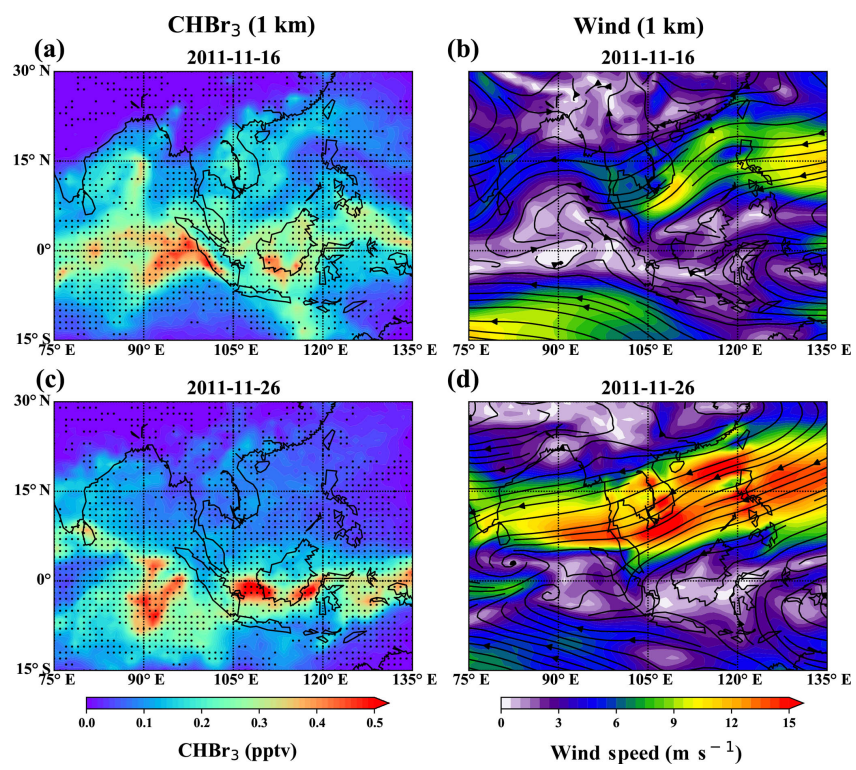

Figure 3. Same as Fig. 2, but for the SHIVA case.

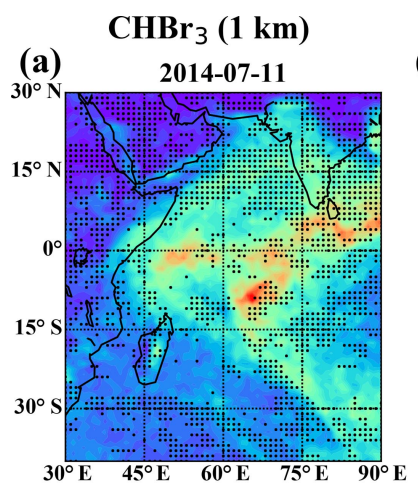

(c)
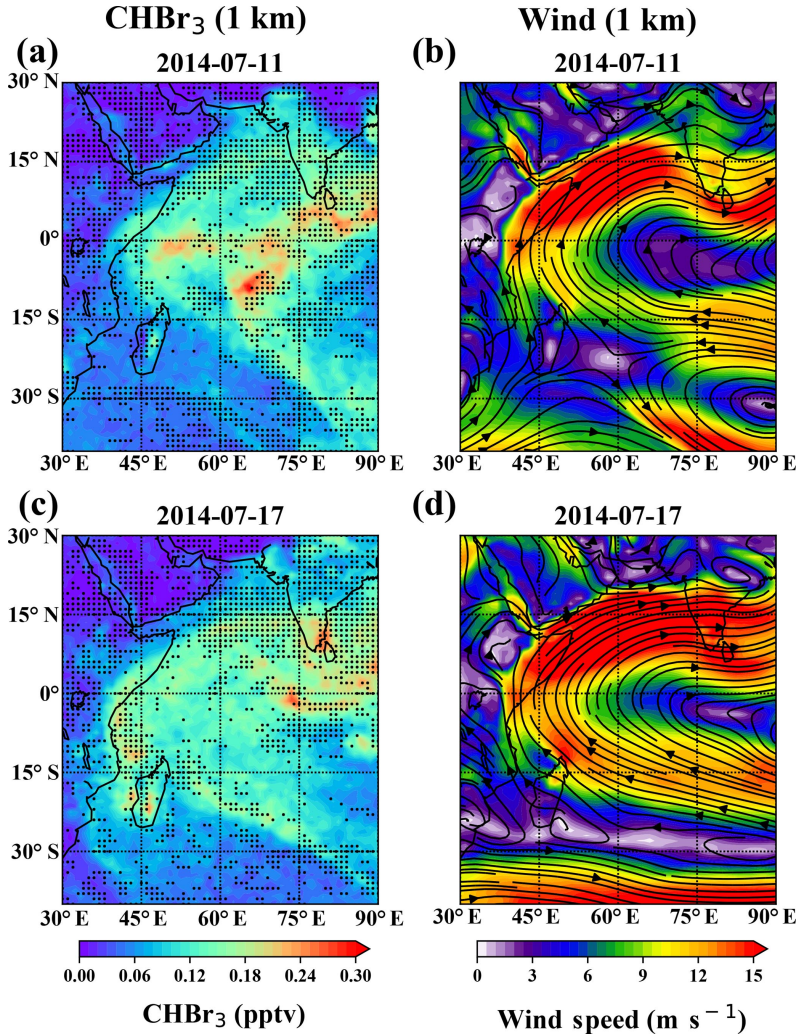

(d)

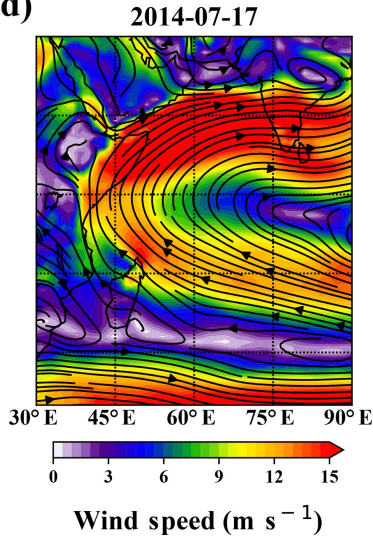

Figure 4. Same as Fig. 2, but for the OASIS case.

winds, the background values for the OASIS case are significantly lower than for the other two cases, although they also show accumulations in certain regions. These relatively higher background mixing ratios appear partially in regions of low wind speeds (e.g., near the Equator between 70 and $90^{\circ} \mathrm{E}$ on $17 \mathrm{July}$ ) or in adjacent regions of high wind shear (e.g., north of the Equator between 70 and $90^{\circ} \mathrm{E}$ for both case studies). For the latter case, the $\mathrm{CHBr}_{3}$ accumulation also extends into the region of high wind speeds, which is different from the distribution found for the TransBrom and SHIVA regions. This difference occurs because the east coast of the Indian subcontinent offshore is a region with wind convergence (dotted region), which tends to accumulate air masses therein.

Given that the accumulation of $\mathrm{CHBr}_{3}$ background mixing ratios follows the wind field patterns on a regional scale in most cases, we hypothesize that the interplay between wind speed and convergence may influence the $\mathrm{CHBr}_{3}$ distribution.

In order to validate the hypothesis, we show a violin plot of regional background $\mathrm{CHBr}_{3}$ mixing ratios related to convergence-divergence and to the wind speeds averaged over each simulation period in Fig. 5. For the TransBrom case, the averaged ranges of mixing ratios in regions of convergence and divergence (Fig. 5a) go up to 0.7 and $0.5 \mathrm{ppt}$, respectively, with interquartile ranges of $0.1-0.35$ and 0.05 
(a)

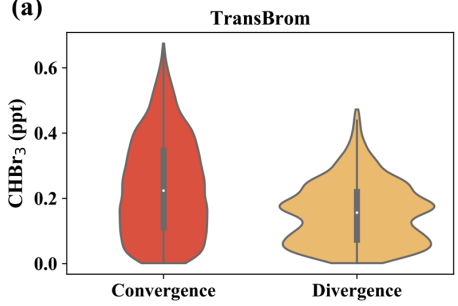

(c)
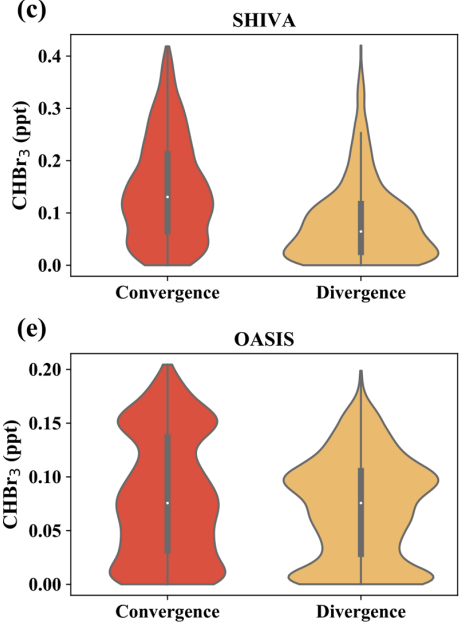

(b)

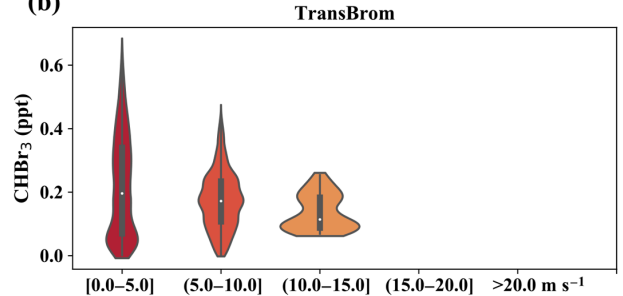

(d)

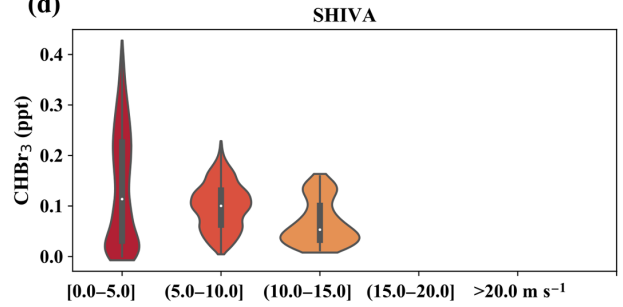

(f)

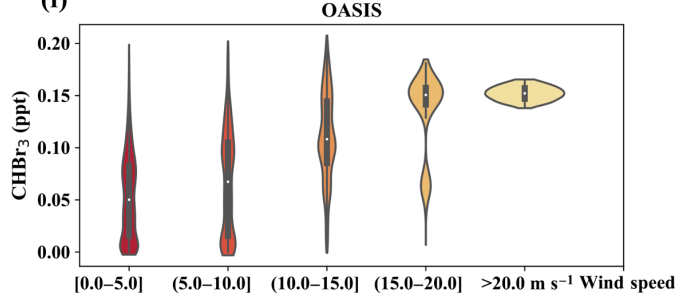

Figure 5. Violin plots of regional distributions of simulated background $\mathrm{CHBr}_{3}$ mixing ratio by convergence and divergence (a, c, e) and by wind speed $(\mathbf{b}, \mathbf{d}, \mathbf{f})$ at $1 \mathrm{~km}$ altitude averaged over TransBrom $(\mathbf{a}, \mathbf{b})$, SHIVA (c, d), and OASIS (e, f). The violin is a corresponding density plot with a boxplot inside. The white dots represent the medians. The thick black bars in the center represent the interquartile ranges. The thin black lines represent the rest of the distributions, except for the outliers.

0.21 ppt. Probability of mixing ratios larger than $0.2 \mathrm{ppt}$ is much higher for regions of convergence compared to regions of divergence. Meanwhile, in the regions grouped by wind speed (Fig. 5b), higher $\mathrm{CHBr}_{3}$ mixing ratios are more likely to occur in regions with lower wind speeds (i.e., in the regions of $0.0-5.0 \mathrm{~m} \mathrm{~s}^{-1}$, mixing ratios go up to $0.65 \mathrm{ppt}$, while in the regions of $10-15 \mathrm{~m} \mathrm{~s}^{-1}$, mixing ratios only go up to $0.25 \mathrm{ppt}$ ). Similar distributions also occur for the SHIVA case. During the OASIS case, the $\mathrm{CHBr}_{3}$ mixing ratios are much smaller than for the other two cases due to stronger winds. The highest mixing ratios $(\sim 0.15$ to $\sim 0.2 \mathrm{ppt})$ are found in the regions of convergence (Fig. 5e). However, higher mixing ratios are also generally found in the regions of higher wind speeds (Fig. 5f), as the regions of convergence are located in the regions of high wind speed during the OASIS case. The distributions suggest that in general higher $\mathrm{CHBr}_{3}$ mixing ratios tend to occur in the regions of convergence or lower wind speed, with the exception of the OASIS case where extremely high winds occurred and coincided with regions of convergence.

The relationship mentioned above also holds on a global scale. The global distributions of atmospheric $\mathrm{CHBr}_{3}$ based on background emissions and wind fields averaged over the time periods of the SHIVA and OASIS campaigns are presented in Figs. 6 and 7. We omit the time period of the Trans-
Brom case since the background $\mathrm{CHBr}_{3}$ distribution diagnosed for this period is very similar to the background found for the SHIVA period. The global $\mathrm{CHBr}_{3}$ background mixing ratios (Figs. 6a and 7a) display a very heterogeneous distribution in spite of the uniform background emissions used for the simulations. High $\mathrm{CHBr}_{3}$ mixing ratios are again generally located in the regions of convergence, which also generally correspond to low wind speeds on a global scale. For the SHIVA period (November 2011), particularly high $\mathrm{CHBr}_{3}$ background values of 0.3 to $0.4 \mathrm{ppt}$ are found along the Equator over the Maritime Continent, West Pacific, Indian Ocean, and at the west coast of Africa, all of which are characterized by particularly low winds. In the northern and southeast $\mathrm{Pa}$ cific, the wind speed is generally higher, and the corresponding $\mathrm{CHBr}_{3}$ values of less than $0.15 \mathrm{ppt}$ are much lower than in the tropical region. For the OASIS period (July-August 2014), the global $\mathrm{CHBr}_{3}$ distribution is mostly reversed compared to the SHIVA period and high winds over the Indian Ocean and Maritime Continent lead to low $\mathrm{CHBr}_{3}$ abundance in this region. The North Pacific on the other hand, with low wind speeds, is now a region of intense accumulation leading to $0.3-0.4$ ppt of $\mathrm{CHBr}_{3}$. The tropical West Pacific is the only region that experiences relatively low winds during both seasons, and constantly shows high $\mathrm{CHBr}_{3}$ for the SHIVA and OASIS time periods. 


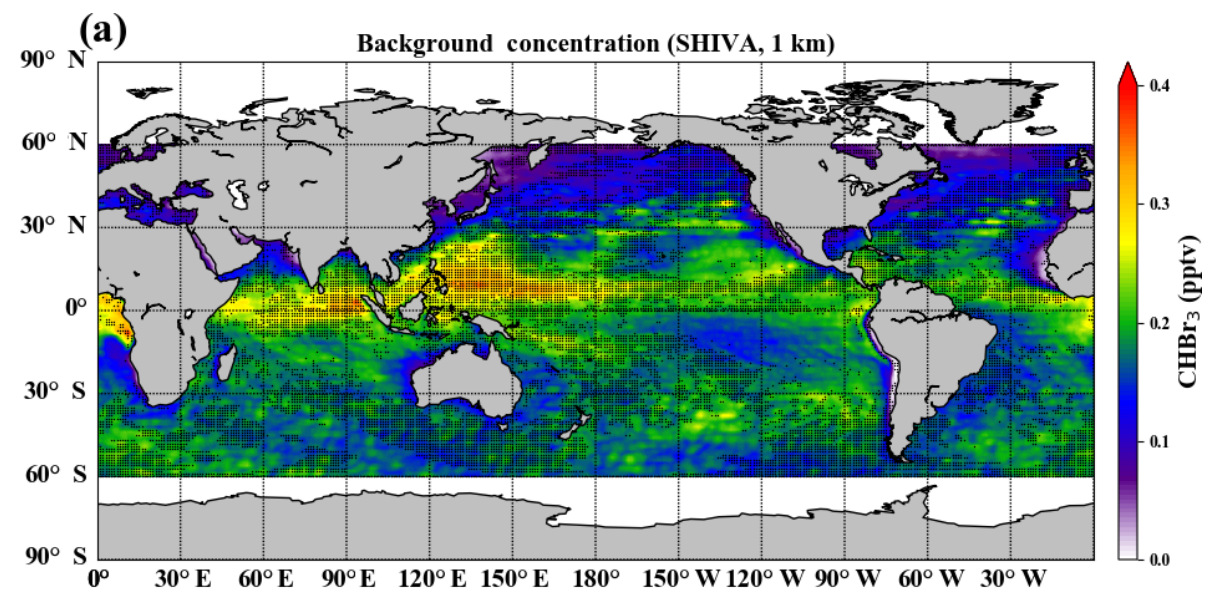

(b)

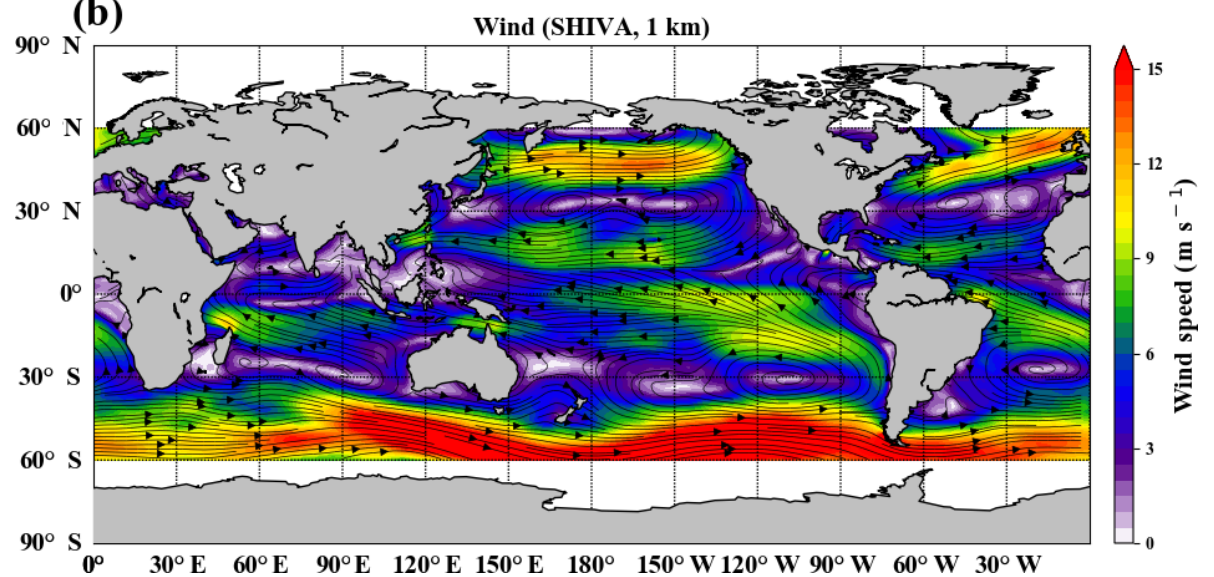

Figure 6. Global distributions of $\mathrm{CHBr}_{3}$ mixing ratios based on oceanic background emissions (a) and ERA-Interim reanalysis wind fields (b) averaged during the time period of the SHIVA cruise at $1 \mathrm{~km}$. The wind speeds are denoted by color shades and the directions are denoted by the stream lines. The regions of convergence are shaded in (a).

The variations in the background $\mathrm{CHBr}_{3}$ distribution can be generally explained by the seasonal variations in the global wind field. The North Pacific and northern Indian Ocean are dominated by the East Asia Monsoon and the monsoon of South Asia, respectively. The East Asia Monsoon is characterized by strong northwesterly flow in boreal winter and weak southeasterly flow in boreal summer due to the reverse of the thermal gradient between land and ocean (Webster, 1987; Ding and Chan, 2005). Therefore, the accumulations of $\mathrm{CHBr}_{3}$ in the North Pacific occur during the boreal summer months, rather than during boreal autumn and early winter (TransBrom time period). The monsoon of South Asia, on the other hand, is characterized by weak northeasterly winds in boreal winter and strong southwesterly winds in boreal summer (Webster, 1987; Webster et al., 1998). Thus background $\mathrm{CHBr}_{3}$ accumulation over the northern Indian Ocean occurs mostly during boreal winter, while during boreal summer (OASIS time period) a low $\mathrm{CHBr}_{3}$ background can be expected. Because of the light winds of the Inter-tropical Convergence Zone (ITCZ), a belt of relatively high $\mathrm{CHBr}_{3}$ abundance exists along the Equator in the Northern Hemisphere, especially in the tropical Pacific and Atlantic. Strong convection in the ITCZ enhances vertical transport of $\mathrm{CHBr}_{3}$ out of the boundary layer, but overall the $\mathrm{CHBr}_{3}$ distribution is dominated by the horizontal wind fields and accompanying transport patterns. Due to the more complex land-sea thermal difference, the seasonal variations in ITCZ in the West Pacific is more significant than in the East Pacific (Waliser and Jiang, 2014). The relatively high accumulations of $\mathrm{CHBr}_{3}$ in the tropical East $\mathrm{Pa}$ cific are confined to a narrow region near the Equator for both seasons. As for the tropical West Pacific, during boreal winter the ITCZ covers almost all of Southeast Asia and the high $\mathrm{CHBr}_{3}$ abundances during SHIVA appear along the east coast of Malaysia. During boreal summer, the ITCZ shifts northward and the high $\mathrm{CHBr}_{3}$ abundances retreat northwestward.

In the above simulations, we assume a constant background emission in order to isolate the impact of transport and loss processes on the atmospheric $\mathrm{CHBr}_{3}$ distribution. Variations in the wind fields will likely impact the oceanic air-sea flux and emissions. Such variations can change the 

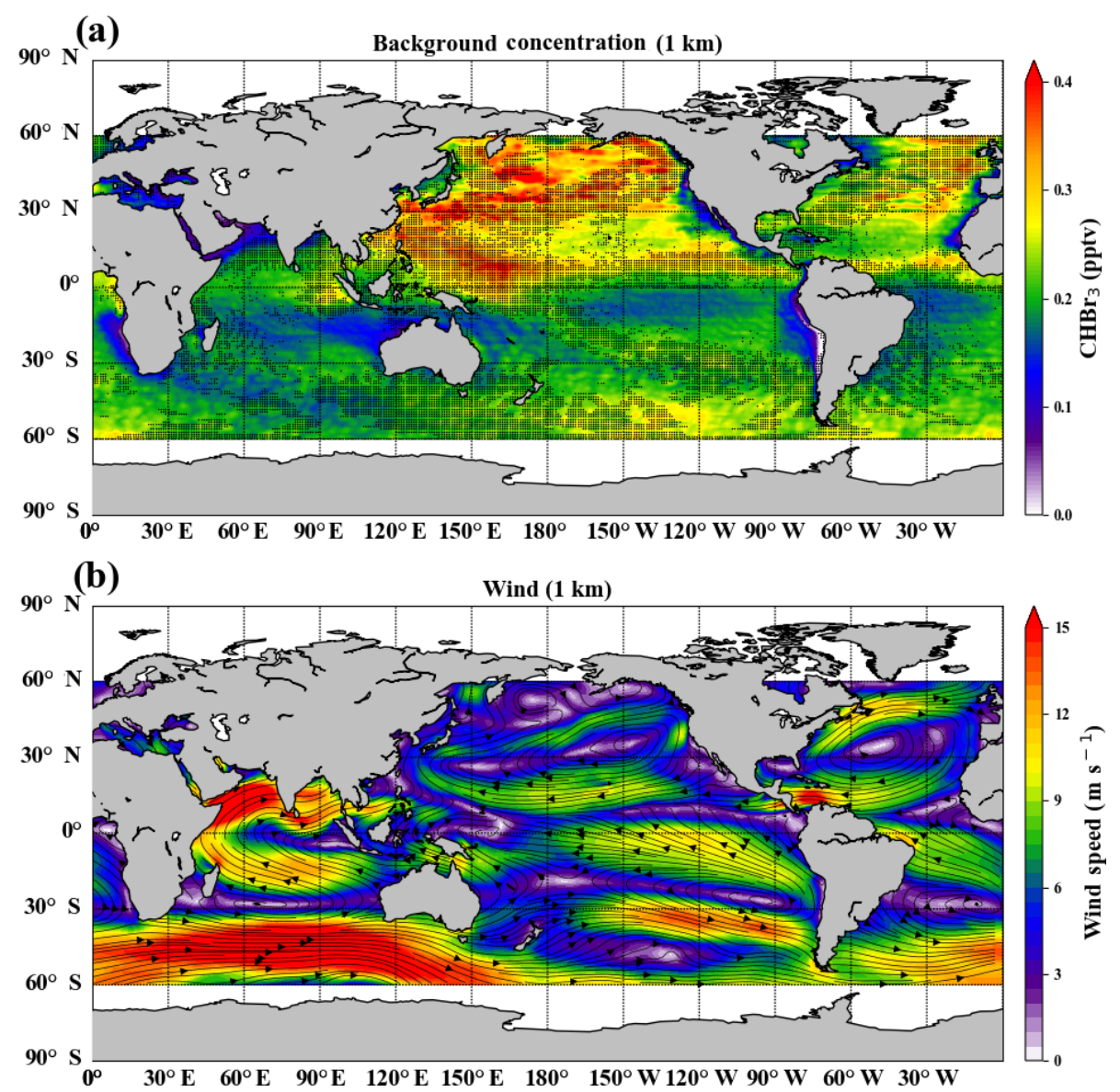

Figure 7. Same as Fig. 6, but for the OASIS case.

background $\mathrm{CHBr}_{3}$ distribution and may allow for increased mixing ratios in regions of strong winds. In addition to the wind speed, variations in the atmospheric and, more importantly, the oceanic $\mathrm{CHBr}_{3}$ concentrations can impact the emission strength, which can further change the complex atmospheric $\mathrm{CHBr}_{3}$ distribution.

\section{Atmospheric $\mathrm{CHBr}_{3}$ based on hot spot emissions}

Given the high variability of the atmospheric $\mathrm{CHBr}_{3}$ background mixing ratios, resulting from atmospheric transport processes (Sect. 3), it is of interest to analyze if and how much oceanic hot spot emissions might impact this background distribution. In this section, the results of simulations based on observed localized hot spot emissions will be compared to the background mixing ratios.

\subsection{Observed hot spot emissions}

Oceanic $\mathrm{CHBr}_{3}$ emissions, atmospheric $\mathrm{CHBr}_{3}$ mixing ratios, and the observed local surface wind speeds are given in Fig. 8 for all three campaigns. The oceanic emissions of $\mathrm{CHBr}_{3}$ vary substantially from campaign to campaign with mean values of $261 \mathrm{pmolh}^{-1} \mathrm{~m}^{-2}$ (TransBrom), $1228 \mathrm{pmol} \mathrm{h}^{-1} \mathrm{~m}^{-2}$ (SHIVA), and $912 \mathrm{pmolh}^{-1} \mathrm{~m}^{-2}$ (OASIS) with standard deviations of $600 \mathrm{pmolh}^{-1} \mathrm{~m}^{-2}$ (TransBrom), $1460 \mathrm{pmol} \mathrm{h}^{-1} \mathrm{~m}^{-2} \quad$ (SHIVA), and $1159 \mathrm{pmol} \mathrm{h}^{-1} \mathrm{~m}^{-2}$ (OASIS), respectively (Tegtmeier et al., 2012; Ziska et al., 2013; Fuhlbrügge et al., 2016; Fiehn et al., 2017).

All three campaigns show periods with localized elevated and hot spot emissions. For TransBrom, the first two-thirds of the campaign show negative (into the ocean) or very low $\mathrm{CHBr}_{3}$ fluxes, while the last third was close to western $\mathrm{Pa}-$ cific islands and is characterized by overall elevated emissions with sporadic hot spots of up to $4000 \mathrm{pmol} \mathrm{h}^{-1} \mathrm{~m}^{-2}$. The SHIVA cruise track was mostly along the coastline, where elevated emissions and hot spots occurred regularly. The OASIS cruise track alternated between open ocean, upwelling, and coastal areas, resulting in a large fluctuation between low background and localized elevated emissions. The largest hot spot emissions were observed during this campaign, reaching values of over $6000 \mathrm{pmol} \mathrm{h}^{-1} \mathrm{~m}^{-2}$.

According to the flux parameterization applied here, the variability of air-sea flux is determined mostly by the surface wind speed and the ocean-atmosphere concentration gradi- 

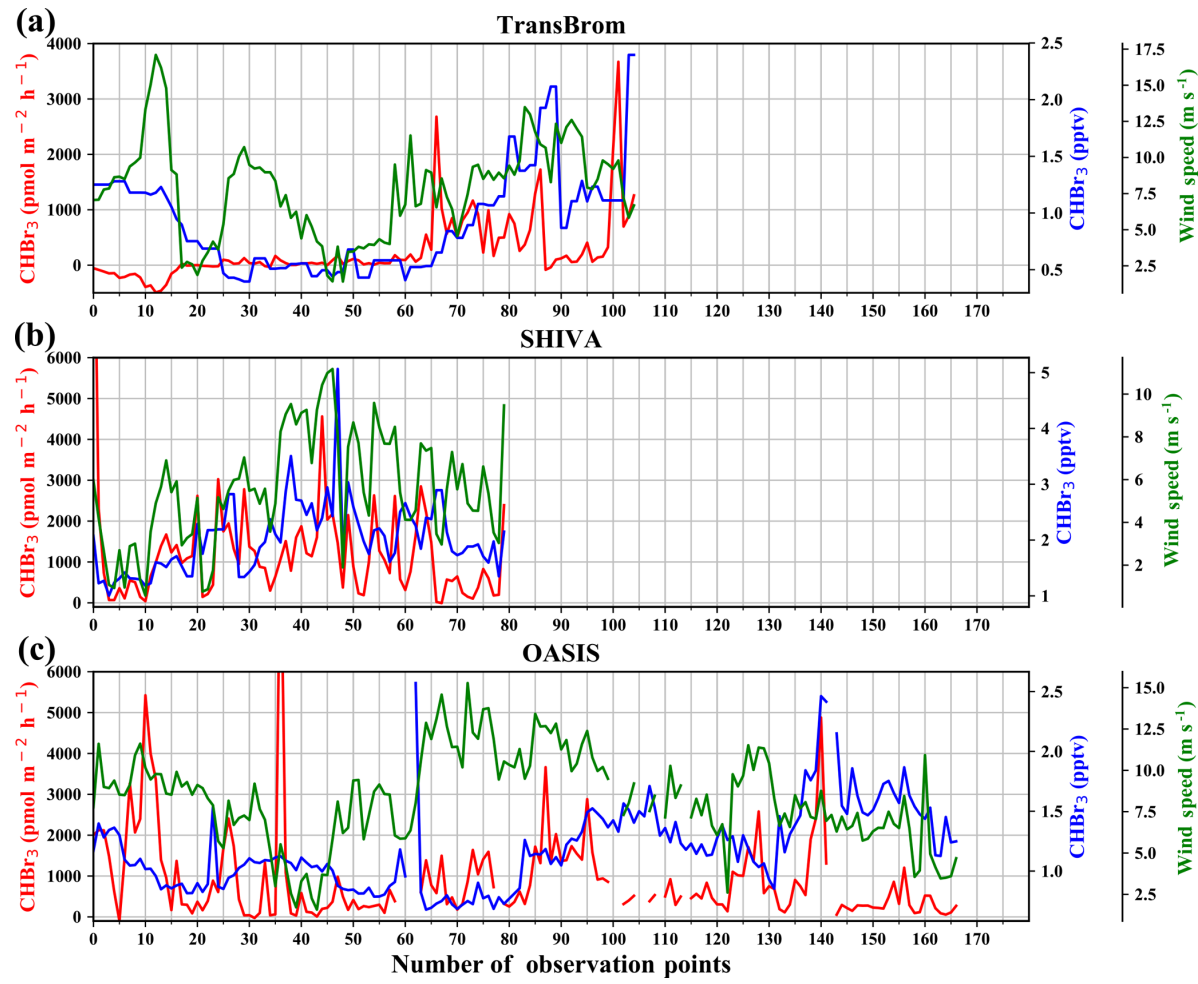

Figure 8. Surface wind speeds (green), $\mathrm{CHBr}_{3}$ air-sea flux (red), and atmospheric mixing ratios of $\mathrm{CHBr}_{3}$ near the surface (blue) observed during the TransBrom, SHIVA, and OASIS campaigns.

ent. The highest emissions are expected to occur during periods of high wind speeds and large concentration gradients. During the beginning of the TransBrom campaign (Fig. 8a), the wind speed peaks at over $15 \mathrm{~m} \mathrm{~s}^{-1}$ while the corresponding $\mathrm{CHBr}_{3}$ air-sea flux is low. Higher wind speeds co-occur with high air-sea fluxes at the end of the campaign. For SHIVA (Fig. 8b) and OASIS (Fig. 8c), the relation between wind speed and $\mathrm{CHBr}_{3}$ emissions is more easily discernable.

All three campaigns demonstrate that high fluxes do not always lead to local high $\mathrm{CHBr}_{3}$ mixing ratios in the surface atmosphere. For example, several hot spots with oceanic emissions over $4000 \mathrm{pmol} \mathrm{m}^{-2} \mathrm{~h}^{-1}$ are found during OASIS; however, corresponding atmospheric mixing ratios are relatively low $(\sim 2 \mathrm{ppt})$. Vice versa, the highest atmospheric mixing ratios found during OASIS only coincide with high fluxes during the last part of the campaign. These discrepancies underline how the complex interplay of source, transport, and loss processes impact on the local atmospheric mixing ratios of short-lived compounds. A relatively clear connection between elevated oceanic emissions and surface mixing ratios only occurs during the SHIVA campaign and during the last part of the TransBrom campaign (Fig. 8a and b).

The question arises of how much of the atmospheric variability of short-lived compounds such as $\mathrm{CHBr}_{3}$ is impacted by the emission strengths and is addressed in the subsequent section based on the model results.

\subsection{Comparison of $\mathrm{CHBr}_{3}$ from background and hot spot emissions}

In this section, we compare the concentrations of $\mathrm{CHBr}_{3}$ due to background and localized elevated emissions as simulated by FLEXPART. Atmospheric background and hot spot $\mathrm{CHBr}_{3}$ at different altitudes is simulated by FLEXPART, which is driven by the meteorological data from ECMWF. The signatures of dynamical processes such as wind regimes, weather phenomena (e.g., typhoons), and convection are captured by the model simulation and can be detected in the $\mathrm{CHBr}_{3}$ distribution (Fig. 9). For example, during the TransBrom campaign, the cruise encountered several tropical storms in the western Pacific, one of which (Lupit, around 14 October 2009) developed into a super typhoon within several days (Krüger and Quack, 2013). As shown in Fig. 9, $\mathrm{CHBr}_{3}$ accumulation representing the structure of typhoon Lupit is clearly visible in the background distribution of $\mathrm{CHBr}_{3}$ at $500 \mathrm{~m}$ altitude (Fig. 9d) in the northern part of the western Pacific. This structure is still clear at $5 \mathrm{~km}$ altitude (Fig. 9a), although with a weaker magnitude. Localized elevated sources of $\mathrm{CHBr}_{3}$ (Fig. 9b, c, e, and f) do not add much due to the small spatial extent of the 0.5 or $1^{\circ}$ emission cells, and thus the limited amount of overall released $\mathrm{CHBr}_{3}$ is not discernible in the large-scale structures. Higher abundances of atmospheric $\mathrm{CHBr}_{3}$ can be seen in the southern part of the western Pacific near Indonesia resulting from 
one of the hot spot emissions observed during TransBrom (Fig. 1b). However, the background $\mathrm{CHBr}_{3}$ in this area is also high in this low-wind area, and thus the atmospheric signal of the up to 20 times stronger hot spot emissions (Fig. 8a) is not detectable for either the $0.5^{\circ}$ or the $1^{\circ}$ wide emission cells when compared to the background. Note that the modeled atmospheric mixing ratios from both sources, hot spot and background emissions, are smaller than the mixing ratios observed along the cruise track (Fig. 8), suggesting stronger nearby emissions not covered in our scenarios and observations. The signature of the hot spot emissions cannot be seen at $5 \mathrm{~km}$ altitude.

Figure 10 shows the atmospheric $\mathrm{CHBr}_{3}$ mixing ratios during the SHIVA campaign. The atmospheric signal of the localized elevated emissions during SHIVA is much stronger than during TransBrom due to stronger emissions and smaller background mixing ratios. First, for the $0.5^{\circ}$ wide emission grids, two highly localized atmospheric $\mathrm{CHBr}_{3}$ peaks appear close to the coastline near the Equator around $105^{\circ} \mathrm{E}$ with a maximum value around $0.4 \mathrm{ppt}$. These signals occur in a spot where the background is very low $(0.2 \mathrm{ppt})$. However, at the same time they are smaller than the maximum background values of up to $0.5 \mathrm{ppt}$ in nearby regions (Fig. 10d). If the width of the emission grids is extended to $1^{\circ}$, the localized $\mathrm{CHBr}_{3}$ peaks mentioned above grow into two distinct blobs near the Equator of up to $0.8 \mathrm{ppt}$, which are apparently larger than the regional background concentrations (Fig. 10f). Elevated emissions during the second half of the campaign with several hot spot events, on the other hand, do not show such clear atmospheric signals right above.

For the regions of localized elevated emissions, the convection is less effective and maximum mixing ratios at $5 \mathrm{~km}$ are about $50 \%$ smaller compared to the values in the boundary layer. Thus only the signal of the $1^{\circ}$ wide emission cells can be detected at $5 \mathrm{~km}$, while assuming that the emissions covering a smaller region of $0.5^{\circ}$ width will render their impact in the free troposphere negligible. Krysztofiak et al. (2018) calculated the fractions of convective-contributed trace gases from the boundary layer to the upper troposphere using airborne measurements during the SHIVA campaign and reported an even smaller fraction of boundary layer $\mathrm{CHBr}_{3}$ in the upper troposphere (about $15 \%$ due to convection).

Due to the dominant southwest monsoon over the northern Indian Ocean in boreal summer, the resulting atmospheric abundances of the OASIS case (Fig. 11) for both scenarios, background and localized emissions, are much lower than for the other two campaigns. This is particularly surprising for the OASIS hot spot emissions, which are in many cases larger than hot spot emissions during TransBrom or SHIVA. In the open ocean, the atmospheric enhanced $\mathrm{CHBr}_{3}$ mixing ratios resulting from the $0.5^{\circ}\left(1^{\circ}\right)$ wide localized emission runs reach only $0.1(0.2)$ ppt in a narrow belt near $60^{\circ} \mathrm{E}$ and are mostly smaller than the background (around $0.15 \mathrm{ppt}$ ).
An exception occurs near the coast of Madagascar, where both background and hot spot emissions accumulate in the atmosphere. Maximum background values reach up to $0.25 \mathrm{ppt}$ and the hot spot signals peak with values of $0.3 \mathrm{ppt}\left(0.5^{\circ}\right.$ wide emission cells) to $0.6 \mathrm{ppt}\left(1^{\circ}\right.$ wide emissions cells). These clear atmospheric signals of hot spot emissions are driven by the enhanced coastal emissions near Madagascar. At $5 \mathrm{~km}$ altitude, atmospheric background values are very low, and the hot spot contributions are close to zero.

In summary, although the observed emissions during the three cruises were significantly higher than the background of $100 \mathrm{pmol} \mathrm{m}^{-2} \mathrm{~h}^{-1}$, our results show that such strong oceanic sources are not necessarily detectable in the atmosphere, where transport processes can mask the impact of oceanic emissions.

\section{Summary and discussion}

In this study, we simulated atmospheric $\mathrm{CHBr}_{3}$ abundances that result from uniform marine background emissions compared to hot spot emissions using the Lagrangian dispersion model FLEXPART.

The simulations demonstrate that uniform background emissions from the ocean result in a highly variable atmospheric $\mathrm{CHBr}_{3}$ distribution with high mixing ratios taking place in regions of convergence or low wind speed. This relation holds on regional and global scales, underlining the role of atmospheric transport processes as drivers of the distribution of short-lived trace gases with lifetimes in the range of days to weeks. The relation between atmospheric background and wind patterns described here will allow us to better predict the seasonal and regional characteristics of the tropospheric $\mathrm{CHBr}_{3}$ distribution. Such knowledge will provide valuable information for analyzing and interpreting atmospheric data from ship and aircraft campaigns. For example, our results illustrate that elevated or low atmospheric $\mathrm{CHBr}_{3}$ abundances cannot necessarily be used to draw conclusions about the oceanic source strength below.

Comparisons between atmospheric $\mathrm{CHBr}_{3}$ resulting from background and peak emissions suggest that the impact of localized elevated emissions on the atmospheric $\mathrm{CHBr}_{3}$ distribution depends on their relative strength, on their location, and on the time of emission. The "visibility" of elevated emissions in the atmospheric $\mathrm{CHBr}_{3}$ distribution varies significantly between three cruises in the West Pacific and Indian oceans. In the open ocean, signals of elevated emissions can hardly be distinguished from the background $\mathrm{CHBr}_{3}$ distribution even for elevated sources extending over $1^{\circ}$ wide source regions along the cruise tracks. Near the coast, however, signals of elevated emissions are often stronger to be distinguished from the background, in particular, hot spot emissions up to 100 times larger than the background. However, individual cases show that it is not necessarily the largest hot spot that gives a clear signal, but that the tug-of- 
TransBrom (date: 2009-10-15)
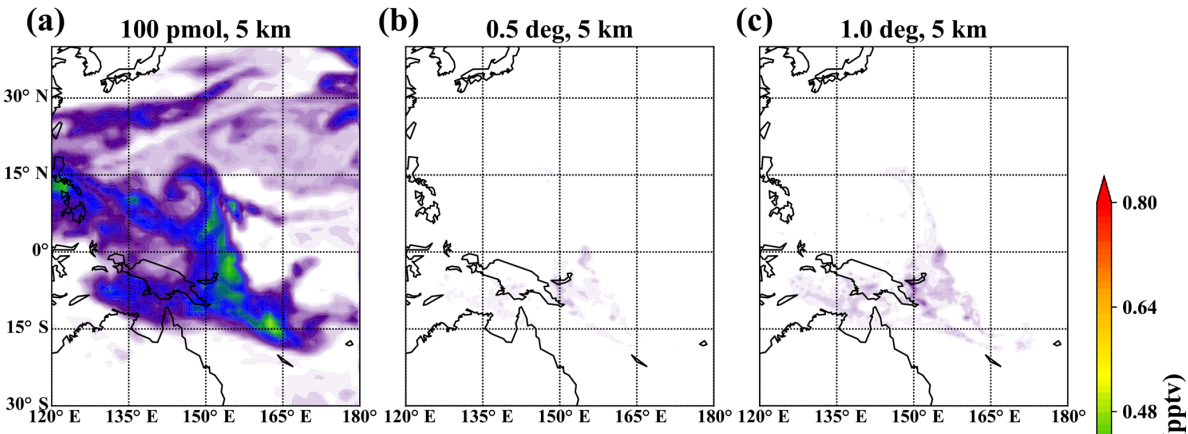

(d) $100 \mathrm{pmol}, 500 \mathrm{~m}$

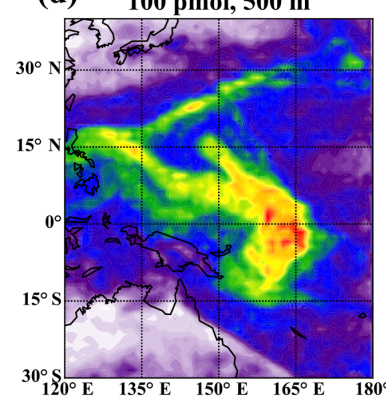

(e)

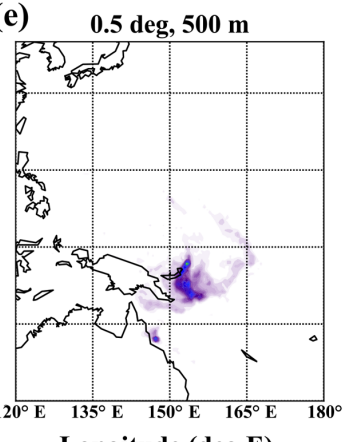

(f)

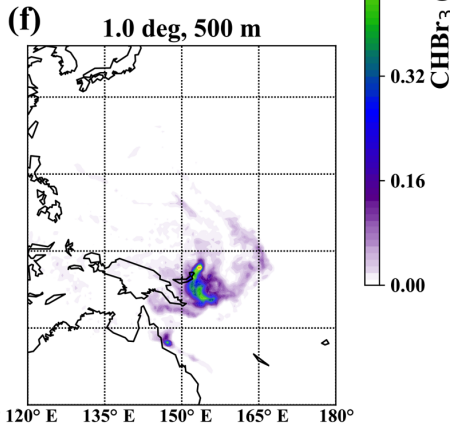

Longitude (deg E)

Figure 9. Atmospheric $\mathrm{CHBr}_{3}$ mixing ratios at different altitudes $(500 \mathrm{~m}$ and $5 \mathrm{~km}$ ) simulated for the time period of the TransBrom campaign. Simulations are based on background emissions (a, d) and elevated emissions observed during the campaign for $0.5^{\circ}(\mathbf{b}, \mathbf{e})$ and $1^{\circ}(\mathbf{c}, \mathbf{f})$ wide emission grid cells.

SHIVA (date: 2011-11-25)

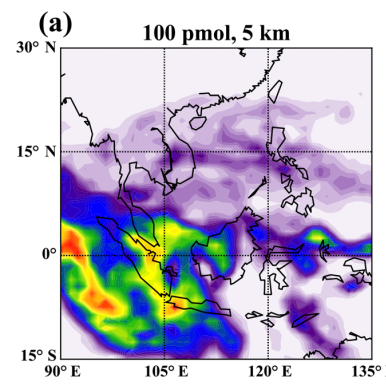

(b)

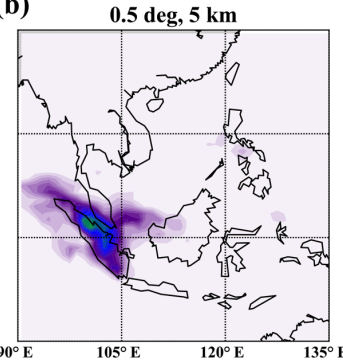

(e)

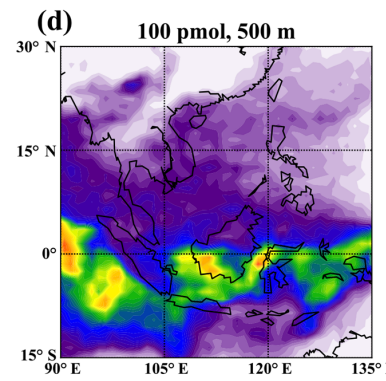

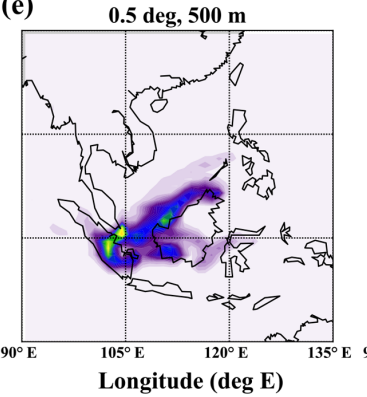

(c)

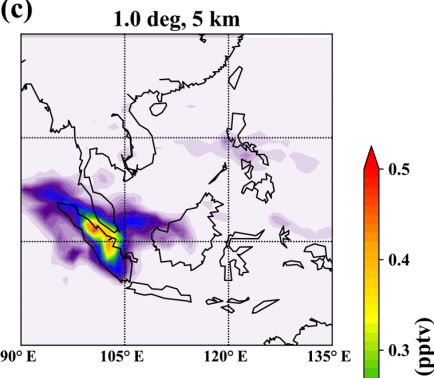

(f) $\quad 1.0 \mathrm{deg}, 500 \mathrm{~m}$

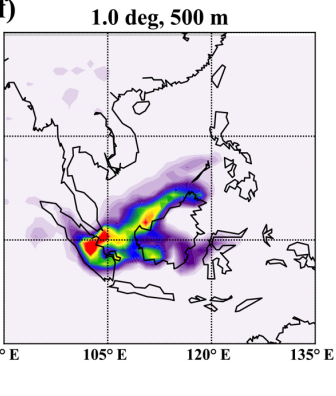

$.3 \frac{3}{3}$

Figure 10. Same as Fig. 9, but for the SHIVA campaign. 
OASIS (date: 2014-07-25)
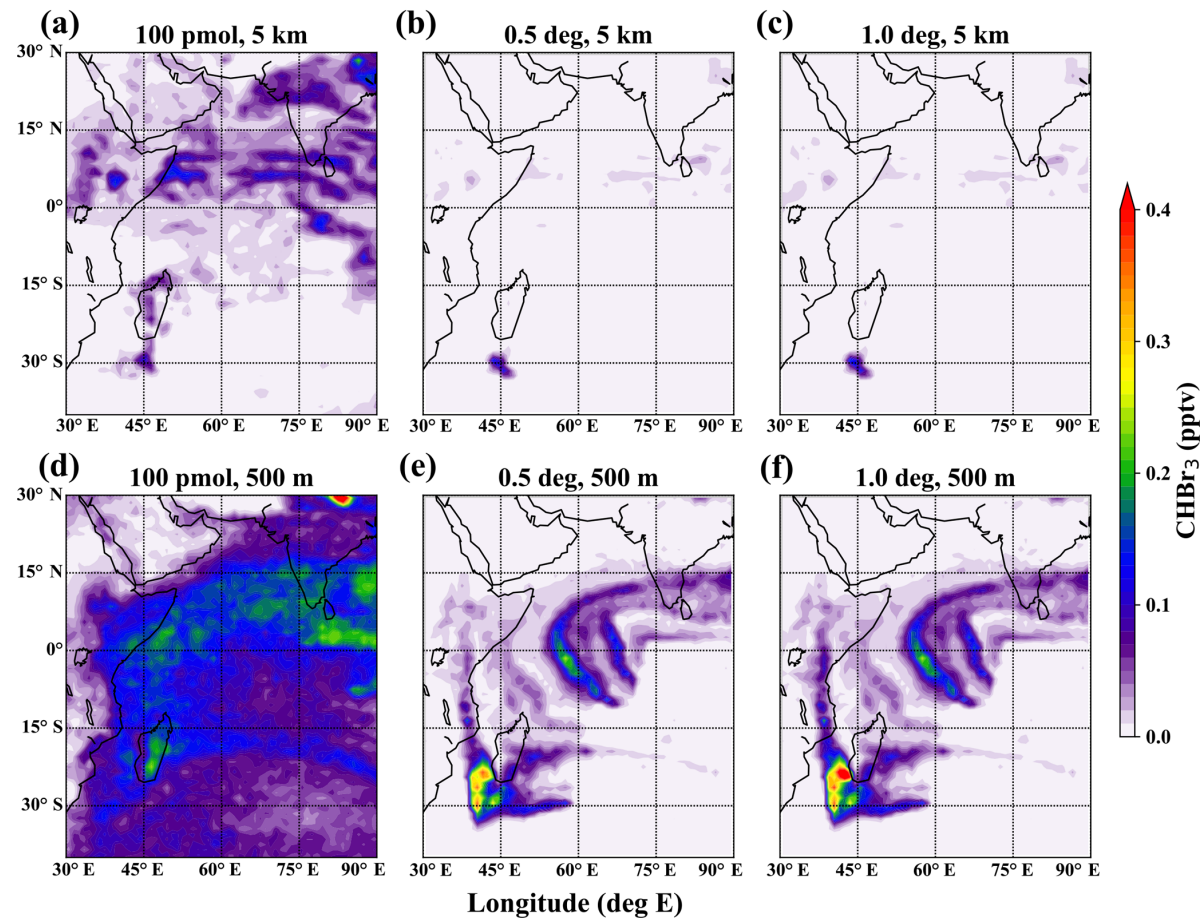

Figure 11. Same as Fig. 9, but for the OASIS campaign.

war between fast advective transport and local accumulation at the time of emission is also important.

Our approach requires that we isolate uniform background $\mathrm{CHBr}_{3}$ emission from coastal and shelf emissions, which can be significant (Fuhlbrügge et al., 2016; Fiehn et al., 2017) and would lead to higher atmospheric abundances. As a consequence, we expect the background $\mathrm{CHBr}_{3}$ mixing ratios inferred from our simulations to be smaller compared to observations and other modeling studies. In the western $\mathrm{Pa}-$ cific (TransBrom), our simulated background mixing ratios at $5 \mathrm{~km}$ range from 0.0 to $0.4 \mathrm{ppt}$ (Figs. 9-11). Measurements from aircraft campaigns in this region, CAST (Harris et al., 2016) and CONTRAST (Pan et al., 2016), show higher $\mathrm{CHBr}_{3}$ mixing ratios of $0.03-0.79$ and $0.20-1.127 \mathrm{ppt}$ between 4 and $6 \mathrm{~km}$. Other model studies (e.g., Hossaini et al., 2016; Butler et al., 2018) based on $\mathrm{CHBr}_{3}$ emission scenarios that include coastal and open ocean sources (e.g., Liang et al., 2010; Ordóñez et al., 2012; Ziska et al., 2013) also suggest the average $\mathrm{CHBr}_{3}$ mixing ratio over $0.5 \mathrm{ppt}$ in this region.

The constant background emissions of $100 \mathrm{pmol} \mathrm{m}^{-2} \mathrm{~h}^{-1}$ used in our study are based on a simplified scenario and do not include coastal emissions. Nevertheless, our results demonstrate that atmospheric $\mathrm{CHBr}_{3}$ signals, produced by localized elevated and even hot spot emissions, orders of magnitudes larger than the average open ocean emissions, can be obliterated by the highly variable atmospheric background. That is to say that transport variations in the atmo- sphere itself are sufficient to allow high concentrations in certain regions and that high concentrations of VSLH in the atmosphere do not always guarantee a strong local or regional source. For observational and modeling studies of VSLHs and other short-lived compounds, the impact of atmospheric transport patterns that are identified here can be used for the interpretation of trace gas distributions and variability.

Data availability. The emission data of cruise campaigns are available at PANGAEA (https://www.pangaea.de/, last access: 7 July 2017). FLEXPART output can be obtained from the authors. The figures were prepared using open-source Python package Matplotlib (Hunter, 2007).

Author contributions. YJ and ST designed the model experiments. YJ carried out the FLEXPART calculations and produced the figures. YJ and ST wrote the paper with contributions and revisions from the co-authors BQ and EA.

Competing interests. The authors declare that they have no conflict of interest.

Acknowledgements. This study was carried out within the EmmyNoether group AVeSH (A new threat to the stratospheric ozone layer from Anthropogenic Very Short-lived Halo-carbons) funded by the 
Deutsche Forschungsgemeinschaft (DFG, German Research Foundation (grant no. TE 1134/1)). The authors would like to thank the European Centre for Medium-Range Weather Forecasts (ECMWF) for the ERA-Interim reanalysis data and the FLEXPART development team for the Lagrangian particle dispersion model used in this publication. The FLEXPART simulations were performed on resources provided by the computing center at Christian-AlbrechtsUniversität in Kiel.

Financial support. The article processing charges for this open-access publication were covered by the Deutsche Forschungsgemeinschaft (DFG, German Research Foundation (grant no. TE 1134/1)).

Review statement. This paper was edited by Anita Ganesan and reviewed by James H. Butler and one anonymous referee.

\section{References}

Agus, E., Voutchkov, N., and Sedlak, D. L.: Disinfection byproducts and their potential impact on the quality of water produced by desalination systems: a literature review, Desalination, 237, 214-237, 2009.

Aschmann, J., Sinnhuber, B.-M., Atlas, E. L., and Schauffler, S. M.: Modeling the transport of very short-lived substances into the tropical upper troposphere and lower stratosphere, Atmos. Chem. Phys., 9, 9237-9247, https://doi.org/10.5194/acp-9-92372009, 2009.

Baker, J. M., Sturges, W. T., Sugier, J., Sunnenberg, G., Lovett, A. A., Reeves, C. E., Nightingale, P. D., and Penkett, S. A.: Emissions of $\mathrm{CH} 3 \mathrm{Br}$, organochlorines, and organoiodines from temperate macroalgae, Chemosphere - Global Change Science 3, 93-106. https://doi.org/10.1016/S1465-9972(00)00021-0, 2000.

Boudjellaba, D., Dron, J., Revenko, G., Démelas, C., and Boudenne, J. L.: Chlorination by-product concentration levels in seawater and fish of an industrialised bay (Gulf of Fos, France) exposed to multiple chlorinated effluents, Sci. Total Environ., 541, 391-399, https://doi.org/10.1016/j.scitotenv.2015.09.046, 2016.

Butler, J. H., King, D. B., Lobert, J. M., Montzka, S. A., YvonLewis, S. A., Hall, B. D., Warwick, N. J., Mondeel, D. J., Aydin, M., and Elkins, J. W.: Oceanic distributions and emissions of short-lived halocarbons, Global Biogeochem. Cy., 21, GB1023, https://doi.org/10.1029/2006GB002732, 2007.

Butler, R., Palmer, P. I., Feng, L., Andrews, S. J., Atlas, E. L., Carpenter, L. J., Donets, V., Harris, N. R. P., Montzka, S. A., Pan, L. L., Salawitch, R. J., and Schauffler, S. M.: Quantifying the vertical transport of $\mathrm{CHBr}_{3}$ and $\mathrm{CH}_{2} \mathrm{Br}_{2}$ over the western Pacific, Atmos. Chem. Phys., 18, 13135-13153, https://doi.org/10.5194/acp-18-13135-2018, 2018.

Carpenter, L. J. and Liss, P. S.: On temperate sources of $\mathrm{CHBr}_{3}$ and other reactive organic bromine gases, J. Geophys. Res., 105, 20539-20548, 2000.

Carpenter, L. J., Jones, C. E., Dunk, R. M., Hornsby, K. E., and Woeltjen, J.: Air-sea fluxes of biogenic bromine from the tropical and North Atlantic Ocean, Atmos. Chem. Phys., 9, 1805-1816, https://doi.org/10.5194/acp-9-1805-2009, 2009.
Carpenter, L. J., Reimann, S., Burkholder, J. B., Clerbaux, C., Hall, B. D., Hossaini, R., Laube, J. C., and Yvon-Lewis, S. A.: Ozone-Depleting Substances (ODSs) and other gases of interest to the Montreal Protocol, in: Scientific Assessment of Ozone Depletion: 2014. Global Ozone Research and monitoring Project - Report No. 55, World Meteorological Organization, Geneva, Switzerland, 2014.

Dee, D. P., Uppala, S. M., Simmons, A. J., Berrisford, P., Poli, P., Kobayashi, S., Andrae, U., Balmaseda, M. A., Balsamo, G., Bauer, P., Bechtold, P., Beljaars, A. C. M., van de Berg, L., Bidlot, J., Bormann, N., Delsol, C., Dragani, R., Fuentes, M., Geer, A. J., Haimberger, L., Healy, S. B., Hersbach, H., Hólm, E. V., Isaksen, L., Kållberg, P., Köhler, M., Matricardi, M., McNally, A. P., Monge-Sanz, B. M., Morcrette, J.-J., Park, B.-K., Peubey, C., de Rosnay, P., Tavolato, C., Thépaut, J.-N., and Vitart, F.: The ERA-Interim reanalysis: configuration and performance of the data assimilation system, Q. J. Roy. Meteor. Soc., 137, 553-597, 2011.

Ding, Y. H. and Chan, J. C. L.: The East Asian summer monsoon: An overview, Meteorol. Atmos. Phys., 89, 117-142, 2005.

Dvortsov, V. L., Geller, M. A., Solomon, S., Schauffler, S. M., Atlas, E. L., and Blake, D. R.: Rethinking reactive halogen budgets in the midlatitude lower stratosphere, Geophys. Res. Lett., 26, 1699-1702, https://doi.org/10.1029/1999g1900309, 1999.

Emanuel, K. A. and Živković-Rothman, M.: Development and evaluation of a convection scheme for use in climate models, J. Atmos. Sci., 56, 1766-1782, 1999.

Feng, W., Chipperfield, M. P., Dorf, M., Pfeilsticker, K., and Ricaud, P.: Mid-latitude ozone changes: studies with a 3-D CTM forced by ERA-40 analyses, Atmos. Chem. Phys., 7, 2357-2369, https://doi.org/10.5194/acp-7-2357-2007, 2007.

Fiehn, A., Quack, B., Hepach, H., Fuhlbrügge, S., Tegtmeier, S., Toohey, M., Atlas, E., and Krüger, K.: Delivery of halogenated very short-lived substances from the west Indian Ocean to the stratosphere during the Asian summer monsoon, Atmos. Chem. Phys., 17, 6723-6741, https://doi.org/10.5194/acp17-6723-2017, 2017.

Forster, C., Stohl, A., and Seibert, P.: Parameterization of Convective Transport in a Lagrangian Particle Dispersion Model and Its Evaluation, J. Appl. Meteorol. Clim., 46, 403-422, https://doi.org/10.1175/JAM2470.1, 2007.

Fuhlbrügge, S., Krüger, K., Quack, B., Atlas, E., Hepach, H., and Ziska, F.: Impact of the marine atmospheric boundary layer conditions on VSLS abundances in the eastern tropical and subtropical North Atlantic Ocean, Atmos. Chem. Phys., 13, 6345-6357, https://doi.org/10.5194/acp-13-6345-2013, 2013.

Fuhlbrügge, S., Quack, B., Tegtmeier, S., Atlas, E., Hepach, H., Shi, Q., Raimund, S., and Krüger, K.: The contribution of oceanic halocarbons to marine and free tropospheric air over the tropical West Pacific, Atmos. Chem. Phys., 16, 7569-7585, https://doi.org/10.5194/acp-16-7569-2016, 2016.

Harris, N. R. P., Carpenter, L. J., Lee, J. D., Vaughan, G., Filus, M. T., Jones, R. L., OuYang, B., Pyle, J. A., Robinson, A. D., Andrews, S. J., Lewis, A. C., Minaeian, J., Vaughan, A., Dorsey, J. R., Gallagher, M. W., Breton, M. L., Newton, R., Percival, C. J., Ricketts, H. M. A., Baugitte, S. J.-B., Nott, G. J., Wellpott, A., Ashfold, M. J., Flemming, J., Butler, R., Palmer, P. I., Kaye, P. H., Stopford, C., Chemel, C., Boesch, H., Humpage, N., Vick, A., MacKenzie, A. R., Hyde, R., Angelov, P., 
Meneguz, E., and Manning, A. J.: Co-ordinated Airborne Studies in the Tropics (CAST), B. Am. Meteorol. Soc., 98, 145-162, https://doi.org/10.1175/BAMS-D-14-00290.1, 2016.

Hepach, H., Quack, B., Ziska, F., Fuhlbrügge, S., Atlas, E. L., Krüger, K., Peeken, I., and Wallace, D. W. R.: Drivers of diel and regional variations of halocarbon emissions from the tropical North East Atlantic, Atmos. Chem. Phys., 14, 1255-1275, https://doi.org/10.5194/acp-14-1255-2014, 2014.

Hossaini, R., Chipperfield, M. P., Feng, W., Breider, T. J., Atlas, E., Montzka, S. A., Miller, B. R., Moore, F., and Elkins, J.: The contribution of natural and anthropogenic very short-lived species to stratospheric bromine, Atmos. Chem. Phys., 12, 371380, https://doi.org/10.5194/acp-12-371-2012, 2012.

Hossaini, R., Chipperfield, M. P., Montzka, S. A., Rap, A., Dhomse, S., and Feng, W.: Efficiency of short-lived halogens at influencing climate through depletion of stratospheric ozone, Nat. Geosci., 8, 186-190, https://doi.org/10.1038/ngeo2363, 2015.

Hossaini, R., Patra, P. K., Leeson, A. A., Krysztofiak, G., Abraham, N. L., Andrews, S. J., Archibald, A. T., Aschmann, J., Atlas, E. L., Belikov, D. A., Bönisch, H., Carpenter, L. J., Dhomse, S., Dorf, M., Engel, A., Feng, W., Fuhlbrügge, S., Griffiths, P. T., Harris, N. R. P., Hommel, R., Keber, T., Krüger, K., Lennartz, S. T., Maksyutov, S., Mantle, H., Mills, G. P., Miller, B., Montzka, S. A., Moore, F., Navarro, M. A., Oram, D. E., Pfeilsticker, K., Pyle, J. A., Quack, B., Robinson, A. D., Saikawa, E., Saiz-Lopez, A., Sala, S., Sinnhuber, B.-M., Taguchi, S., Tegtmeier, S., Lidster, R. T., Wilson, C., and Ziska, F.: A multi-model intercomparison of halogenated very shortlived substances (TransCom-VSLS): linking oceanic emissions and tropospheric transport for a reconciled estimate of the stratospheric source gas injection of bromine, Atmos. Chem. Phys., 16, 9163-9187, https://doi.org/10.5194/acp-16-9163-2016, 2016.

Hunter, J. D.: Matplotlib: A 2D Graphics Environment, Comput. Sci. Eng., 9, 90-95, https://doi.org/10.1109/MCSE.2007.55, 2007.

Klick, S. and Abrahamsson, K.: Biogenic volatile iodated hydrocarbons in the ocean, J. Geophys. Res., 97, 12683-12687, 1992.

Krüger, K. and Quack, B.: Introduction to special issue: the TransBrom Sonne expedition in the tropical West Pacific, Atmos. Chem. Phys., 13, 9439-9446, https://doi.org/10.5194/acp-139439-2013, 2013.

Krysztofiak, G., Catoire, V., Hamer, P. D, Marécal, V., Robert, C., Engel, A., Bönisch, H., Grossmann, K., Quack, B., Atlas., E., and Pfeilsticker, K.: Evidence of convective transport in tropical West Pacific region during SHIVA experiment, Atmos. Sci. Lett., 19, e798, https://doi.org/10.1002/asl.798, 2018.

Law, K. S., Sturges, W. T., Blake, D. R., Blake, N. J., Burkeholder, J. B., Butler, J. H., Cox, R. A., Haynes, P. H., Ko, M. K.W., Kreher, K., Mari, C., Pfeilsticker, K., Plane, J. M. C., Salawitch, R. J., Schiller, C., Sinnhuber, B. M., von Glasow, R., Warwick, N. J., Wuebbles, D. J., and Yvon-Lewis, S. A.: Halogenated Very Short-Lived Substances, in: Scientific Assessment of Ozone Depletion: 2006, Global Ozone Research and Monitoring Project - Report No. 50, World Meteorological Organization, Geneva, Switzerland, 2006.

Lennartz, S. T., Marandino, C. A., von Hobe, M., Cortes, P., Quack, B., Simo, R., Booge, D., Pozzer, A., Steinhoff, T., ArevaloMartinez, D. L., Kloss, C., Bracher, A., Röttgers, R., Atlas, E., and Krüger, K.: Direct oceanic emissions unlikely to account for the missing source of atmospheric carbonyl sulfide, Atmos. Chem. Phys., 17, 385-402, https://doi.org/10.5194/acp-17-3852017, 2017.

Liang, Q., Stolarski, R. S., Kawa, S. R., Nielsen, J. E., Douglass, A. R., Rodriguez, J. M., Blake, D. R., Atlas, E. L., and Ott, L. E.: Finding the missing stratospheric Bry: a global modeling study of $\mathrm{CHBr}_{3}$ and $\mathrm{CH}_{2} \mathrm{Br}_{2}$, Atmos. Chem. Phys., 10, 2269-2286, https://doi.org/10.5194/acp-10-2269-2010, 2010.

Liang, Q., Atlas, E., Blake, D., Dorf, M., Pfeilsticker, K., and Schauffler, S.: Convective transport of very short lived bromocarbons to the stratosphere, Atmos. Chem. Phys., 14, 5781-5792, https://doi.org/10.5194/acp-14-5781-2014, 2014.

Liu, Y., Yvon-Lewis, S., Thornton, D., Butler, J., Bianchi, T., Campbell, L., Hu, L., and Smith, R.: Spatial and temporal distributions of bromoform and dibromomethane in the Atlantic Ocean and their relationship with photosynthetic biomass, J. Geophys. Res.Oceans, 118, 3950-3965, 2013.

Marandino, C. A., Tegtmeier, S., Krüger, K., Zindler, C., Atlas, E. L., Moore, F., and Bange, H. W.: Dimethylsulphide (DMS) emissions from the western Pacific Ocean: a potential marine source for stratospheric sulphur?, Atmos. Chem. Phys., 13, 8427-8437, https://doi.org/10.5194/acp-13-8427-2013, 2013.

Montzka, S. A. and Reimann, S.: Ozone-depleting substances and related chemicals, in Scientific Assessment of Ozone Depletion: 2010, Global Ozone Research and Monitoring Project - Report No. 52, WMO, Geneva, Switzerland, 2011.

Ordóñez, C., Lamarque, J.-F., Tilmes, S., Kinnison, D. E., Atlas, E. L., Blake, D. R., Sousa Santos, G., Brasseur, G., and Saiz-Lopez, A.: Bromine and iodine chemistry in a global chemistry-climate model: description and evaluation of very short-lived oceanic sources, Atmos. Chem. Phys., 12, 14231447, https://doi.org/10.5194/acp-12-1423-2012, 2012.

Palmer, C. J. and Reason, C. J.: Relationships of surface bromoform concentrations with mixed layer depth and salinity in the tropical oceans, Global Biogeochem. Cy., 23, GB2014, https://doi.org/10.1029/2008gb003338, 2009.

Pan, L. L., Atlas, E. L., Salawitch, R. J., Honomichl, S. B., Bresch, J. F., Randel, W. J., Apel, E. C., Hornbrook, R. S., Weinheimer, A. J., Anderson, D. C., Andrews, S. J., Baidar, S., Beaton, S. P., Campos, T. L., Carpenter, L. J., Chen, D., Dix, B., Donets, V., Hall, S. R., Hanisco, T. F., Homeyer, C. R., Huey, L. G., Jensen, J. B., Kaser, L., Kinnison, D. E., Koenig, T. K., Lamarque, J.-F., Liu, C., Luo, J., Luo, Z. J., Montzka, D. D., Nicely, J. M., Pierce,R. B., Riemer, D. D., Robinson, T., Romashkin, P., Saiz-Lopez, A., Schauffler, S., Shieh, O., Stell, M. H., Ullmann, K., Vaughan, G., Volkamer, R., and Wolfe, G.: The Convective Transport of Active Species in the Tropics (CONTRAST) Experiment, B. Am. Meteor. Soc., 98, 106-128, https://doi.org/10.1175/BAMS-D-14-00272.1, 2016.

Quack, B. and Wallace, D. W. R.: Air-sea flux of bromoform: Controls, rates, and implications, Global Biogeochem. Cy., 17, 1023, https://doi.org/10.1029/2002gb001890, 2003.

Quack, B., Atlas, E., Petrick, G., Stroud, V., Schauffler, S., and Wallace, D. W. R.: Oceanic bromoform sources for the tropical atmosphere, Geophys. Res. Lett., 31, L23S05, https://doi.org/10.1029/2004GL020597, 2004.

Quack, B., Atlas, E., Petrick, G., and Wallace, D. W. R.: Bromoform and dibromomethane above the Mauritanian upwelling: At- 
mospheric distributions and oceanic emissions, J. Geophys. Res., 112, D09312, https://doi.org/10.1029/2006jd007614, 2007.

Randel, W. J., Park, M., Emmons, L., Kinnison, D., Bernath, P., Walker, K. A., Boone, C., and Pumphrey, H.: Asian monsoon transport of pollution to the stratosphere, Science, 328, 611-613, https://doi.org/10.1126/science.1182274, 2010.

Rex, M., Wohltmann, I., Ridder, T., Lehmann, R., Rosenlof, K., Wennberg, P., Weisenstein, D., Notholt, J., Krüger, K., Mohr, V., and Tegtmeier, S.: A tropical West Pacific $\mathrm{OH}$ minimum and implications for stratospheric composition, Atmos. Chem. Phys., 14, 4827-4841, https://doi.org/10.5194/acp-14-4827-2014 2014.

Salawitch, R., Weisenstein, D., Kovalenko, L., Sioris, C., Wennberg, P., Chance, K., Ko, M., and McLinden, C.: Sensitivity of ozone to bromine in the lower stratosphere, Geophys. Res. Lett., 32, L05811, https://doi.org/10.1029/2004GL021504, 2005.

Solomon, S., Garcia, R. R., and Ravishankara, A. R.: On the role of iodine in ozone depletion, J. Geophys. Res., 99, 20491-20499, https://doi.org/10.1029/94jd02028, 1994.

Stemmler, I., Rothe, M., Hense, I., and Hepach, H.: Numerical modelling of methyl iodide in the eastern tropical Atlantic, Biogeosciences, 10, 4211-4225, https://doi.org/10.5194/bg-104211-2013, 2013.

Stohl, A. and Thomson, D. J.: A density correction for Lagrangian particle dispersion models, Bound.-Lay. Meteorol., 90, 155-167, https://doi.org/10.1023/A:1001741110696, 1999.

Stohl, A. and Trickl, T.: A textbook example of long-range transport: Simultaneous observation of ozone maxima of stratospheric and North American origin in the free troposphere over Europe, J. Geophys. Res., 104, 30445-30462, https://doi.org/10.1029/1999JD900803, 1999.

Stohl, A., Hittenberger, M., and Wotawa, G.: Validation of the lagrangian particle dispersion model FLEXPART against largescale tracer experiment data, Atmos. Environ., 32, 42454264, https://doi.org/10.1016/S1352-2310(98)00184-8, 1998.

Stohl, A., Forster, C., Frank, A., Seibert, P., and Wotawa, G.: Technical note: The Lagrangian particle dispersion model FLEXPART version 6.2, Atmos. Chem. Phys., 5, 2461-2474, https://doi.org/10.5194/acp-5-2461-2005, 2005.

Tegtmeier, S., Krüger, K., Quack, B., Atlas, E. L., Pisso, I., Stohl, A., and Yang, X.: Emission and transport of bromocarbons: from the West Pacific ocean into the stratosphere, Atmos. Chem. Phys., 12, 10633-10648, https://doi.org/10.5194/acp-12-106332012, 2012.
Tegtmeier, S., Krüger, K., Quack, B., Atlas, E., Blake, D. R., Boenisch, H., Engel, A., Hepach, H., Hossaini, R., Navarro, M. A., Raimund, S., Sala, S., Shi, Q., and Ziska, F.: The contribution of oceanic methyl iodide to stratospheric iodine, Atmos. Chem. Phys., 13, 11869-11886, https://doi.org/10.5194/acp-13-118692013, 2013.

Tegtmeier, S., Ziska, F., Pisso, I., Quack, B., Velders, G. J. M., Yang, $\mathrm{X}$., and Krüger, K.: Oceanic bromoform emissions weighted by their ozone depletion potential, Atmos. Chem. Phys., 15, $13647-$ 13663, https://doi.org/10.5194/acp-15-13647-2015, 2015.

Warwick, N. J., Pyle, J. A., Carver, G. D., Yang, X., Savage, N. H., O'Connor, F. M., and Cox, R. A.: Global modeling of biogenic bromocarbons, J. Geophys. Res., 111, D18311, https://doi.org/10.1029/2006jd007264, 2006.

Waliser, D. E. and Jiang, X.: Tropical Meteorology: Intertropical Convergence Zone, Encyclopedia of Atmospheric Sciences, 2nd edn., Elsevier, Academic Press, https://doi.org/10.1016/B978-012-382225-3.00417-5, 2014.

Webster, P. J.: The Elementary Monsoon, 32 pp., John Wiley, New York, 1987.

Webster, P. J., Magaña, V. O., Palmer, T. N., Shukla, J., Tomas, R. A., Yanai, M., and Yasunari, T.: Monsoons: Processes, predictability, and theprospects for prediction, J. Geophys. Res., 103, 14451-14510, https://doi.org/10.1029/97JC02719, 1998.

Yang, J. S.: Bromoform in the effluents of a nuclear power plant: a potential tracer of coastal water masses, Hydrobiologia, 464, 99-105, https://doi.org/10.1023/A:1013922731434, 2001.

Ziska, F., Quack, B., Abrahamsson, K., Archer, S. D., Atlas, E., Bell, T., Butler, J. H., Carpenter, L. J., Jones, C. E., Harris, N. R. P., Hepach, H., Heumann, K. G., Hughes, C., Kuss, J., Krüger, K., Liss, P., Moore, R. M., Orlikowska, A., Raimund, S., Reeves, C. E., Reifenhäuser, W., Robinson, A. D., Schall, C., Tanhua, T., Tegtmeier, S., Turner, S., Wang, L., Wallace, D., Williams, J., Yamamoto, H., Yvon-Lewis, S., and Yokouchi, Y.: Global sea-to-air flux climatology for bromoform, dibromomethane and methyl iodide, Atmos. Chem. Phys., 13, 89158934, https://doi.org/10.5194/acp-13-8915-2013, 2013. 